\title{
ANALISIS KEMAMPUAN PEMECAHAN MASALAH MATEMATIKA SISWA BERDASARKAN TAHAPAN POLYA MATERI SEGIEMPAT
}

\author{
Maria Gaudensia Doa Doko ${ }^{1}$, Sumadji ${ }^{2,}$ Nur Farida $^{3}$ \\ Program Studi Pendidikan Matematika, Universitas Kanjuruhan Malang ${ }^{1,2,3}$ \\ mgaudensia09@gmail.com ${ }^{1}$, sumadji@unikama.ac.id ${ }^{2}$,nurfarida@unikama.ac.id ${ }^{3}$
}

\begin{abstract}
Abstrak: Kemampuan pemecahan masalah siswa pada soal-soal cerita dalam kehidupan sehari-hari masih rendah. Siswa lebih mudah menyelesaikan soal yang hanya menerapkan rumus saja tanpa harus membaca soal cerita. Tahapan pemecahan masalah Polya dianggap mudah dipahami dan banyak digunakan dalam kurikulum matematika di seluruh dunia. Diharapkan dapat membantu siswa lebih runtut dan terstruktur dalam memecahkan masalah matematika. Tujuan penelitian ini, menganalisis kemampuan pemecahan masalah matematika siswa berdasarkan tahapan Polya materi segiempat. Jenis penelitian ini penelitian kualitatif dengan pendekatan studi kasus. Subyek penelitian ini adalah siswa kelas VIIC SMP PGRI 6 Malang. Data penelitian diperoleh dari tes kemampuan pemecahan masalah, wawancara, dan catatan lapangan. Hasil penelitian menunjukkan, subyek yang tergolong pada tingkat 1 yaitu belum mampu melaksanakan empat langkah Polya subyek yang tergolong pada tingkat 2 yaitu hanya mampu memahami masalah , subyek yang tergolong pada tingkat 3 yaitu mampu memahami masalah, menyusun dan melaksanakan rencana penyelesaian , dan subyek yang tergolong pada tingkat 4 yaitu mampu melaksanakan empat langkah polya . Dari uraian tersebut disimpulkan, mayoritas subyek penelitian berada pada tingkat 3 dalam menyelesaikan soal pemecahan masalah segiempat. Saran bagi guru sebaiknya mengetahui kemampuan pemecahan masalah siswa agar pembelajarannya lebih efektif dan berhasil.
\end{abstract}

Kata kunci: analisis pemecahan masalah, Polya; segiempat

\section{PENDAHULUAN}

Ilmu pengetahuan yang mendasari perkembangan teknologi saat ini adalah matematika. Karena peranan matematika sangat penting dalam pemecahan masalah kehidupan sehari-hari (Dewimarni, 2017). Menurut Somawati (2018) pembelajaran matematika merupakan suatu ilmu pengetahuan yang ada di setiap jenjang pendidikan mulai dari sekolah dasar hingga perguruan tinggi yang berfungsi dalam mengembangkan kemampuan berpikir. Salah satu kegiatan dalam pembelajaran matematika yang dapat mengembangkan kemampuan berpikir adalah pemecahan masalah. Lebih lanjut, Suratmi (2017) mengemukakan bahwa kemampuan pemecahan masalah yang harus siswa miliki adalah bagaimana mengatasi permasalahan yang berhubungan dengan kegiatan belajarnya, seperti pada soal matematika. Branca mengungkapkan pentingnya kemampuan pemecahan masalah sebagaimana yang dikutip oleh Sugiman (2009), bahwa tidak hanya sebagai tujuan pembelajaran matematika saja pemecahan masalah merupakan jantungnya matematika. Yang berarti pemecahan masalah merupakan kemampuan dasar yang harus siswa miliki dalam matematika. Kemampuan pemecahan masalah matematika siswa memiliki keterkaitan dengan tahap penyelesaian masalah matematika. Pemecahan masalah matematika merupakan suatu proses untuk menerapkan pengetahuan, keterampilan, dan pemahaman yang diperoleh sebelumnya dengan situasi asing dan baru. Hal penting dalam pembelajaran matematika adalah pemecahan masalah selain itu pemecahan masalah juga merupakan kompetensi strategis yang siswa tunjukkan dalam memahami, memilih pendekatan, strategi pemecahan, dan menyelesaikan masalah dengan menyelesaikan model. Oleh karena itu, siswa harus memiliki gagasan atau ide pemecahan masalah karena pemecahan masalah lebih 
mengutamakan proses dan strategi yang siswa lakukan saat menyelesaikan masalah daripada hanya sekedar hasilnya.

Nahel (Chilmiyah, 2014) mengungkapkan soal cerita dapat digunakan untuk mengetahui kemampuan pemecahan masalah siswa dalam pembelajaran matematika. Soal cerita matematika memiliki peran penting, karena mengutamakan permasalahan-permasalahan real yang sesuai dengan kehidupan sehari-hari. Dewi, dkk (2014) mengungkapkan soal cerita matematika bertujuan supaya siswa terlatih berpikir secara logika deduktif, melihat hubungan dan kegunaan matematika, serta mengasah keterampilan matematika dan memperdalam penguasaan konsep matematika. Ketika siswa mencoba menyelesaikan permasalahan berupa soal cerita, maka siswa tersebut harus mampu melewati berbagai tahapan dalam pemecahan masalah (White, 2010). Salah satu tujuan matematika adalah pada cabang geometri. Pembelajaran geometri memerlukan pemikiran dan penalaran yang kritis serta logis. Materi geometri pada dasarnya akan mudah dipahami oleh siswa dibandingkan cabang matematika lainnya. Kenyataannya, kemampuan siswa memahami materi geometri sangatlah rendah terutama tentang bangun datar. Ketika guru memberikan soal bangun datar yang hanya menerapkan rumus siswa dapat dengan mudah menyelesaikannya. Namun siswa mengalami kesulitan saat diberikan soal cerita materi bangun datar yang berkaitan dengan kehidupan sehari-hari.

Guru bidang studi matematika kelas VII di SMP PGRI 6 Malang, mengungkapkan kemampuan pemecahan masalah siswa ketika menyelesaikan permasalahan matematika berupa soal cerita dalam kehidupan sehari-hari masih rendah dan lebih mudah menyelesaikan soal matematika yang hanya menerapkan rumus tanpa harus membaca soal. Guru berpendapat bahwa siswa sering kali malas membaca soal cerita hal tersebut berdampak siswa mengalami kesulitan dalam menyelesaikan soal matematika. Bocro dan Dapucto (2007) dalam penelitiannya berpendapat bahwa pada saat menyelesaikan soal banyak siswa yang tidak mampu menjawab soal dengan cara yang tepat dan benar. Siswa cenderung menyelesaikan soal yang sama dengan contoh yang guru berikan atau contoh soal yang ada. Mayoritas siswa mengalami kesulitan ketika menyelesaikan soal yang dikaitkan dengan kehidupan sehari-hari dan siswa lebih senang ketika diberikan jawaban namun siswa tidak mau mencari jawaban sendiri.

Polya (dalam Darma Andreas Ngilawajan, 2013) menyarankan empat tahapan sistematis dalam memecahkan masalah, yaitu: memahami masalah (Understanding the problem), membuat rencana penyelesaian (Devising a plan), melaksanakan rencana penyelesaian (Carrying out the plan), dan memeriksa kembali (Looking back). Berdasarkan empat tahapan pemecahan masalah Polya tersebut, Herlambang (2013) mengusulkan empat tingkatan kemampuan siswa dalam menyelesaikan soal cerita sebagai berikut :

1. Tingkat 1 : Subyek belum mampu melaksanakan keempat tahapan pemecahan masalah Polya.

2. Tingkat 2: Subyek mampu memahami masalah.

3. Tingkat 3: Subyek mampu melaksanakan tahap memahami masalah, tahap menyusun rencana penyelesaian, dan tahap melaksanakan rencana penyelesaian.

4. Tingkat 4: Subyek mampu melaksanakan empat tahapan pemecahan masalah Polya.

Tahapan pemecahan masalah Polya dianggap sebagai tahapan pemecahan yang mudah dipahami dan banyak digunakan di seluruh dunia. Diharapkan dengan menggunakan tahapan pemecahan masalah Polya siswa lebih runtut dan terstruktur saat menyelesaikan soal pemecahan masalah matematika. 


\section{METODE PENELITIAN}

Pendekatan yang digunakan pada penelitian ini adalah pendekatan kualitatif dengan jenis penelitian studi kasus dan bersifat deskriptif. Subjek penelitian ini adalah siswa kelas VII C SMP PGRI 6 Malang. Data pada penelitian ini diperoleh dari lembar kerja tes kemampuan pemecahan masalah matematika siswa, tes yang diberikan ialah tes tertulis berbentuk soal uraian materi segiempat sebanyak 4 butir. Deskripsi hasil wawancara, wawancara dilakukan untuk memperoleh informasi yang lebih mendalam terkait kemampuan pemecahan masalah siswa dalam menyelesaikan soal tes berdasarkan tahapan Polya. Catatan lapangan, dalam penelitian ini catatan lapangan merupakan catatan tertulis terkait apa yang dilihat, didengar, dipikirkan, dan dialami guna pengumpulan data dan refleksi data dalam penelitian kualitatif (Bogdan dan Biklen dalam Moleong, 2013). Pengecekan keabsahan data dilakukan dengan menggunakan triangulasi sumber yang dilakukan dengan membandingkan data secara tertulis yaitu hasil tes kemampuan pemecahan masalah dengan data lisan dari hasil wawancara dan catatan lapangan. Analisis dilakukan dengan menggunakan teknik analisis data penelitian kualitatif meliputi reduksi data, penyajian data, dan penarikan kesimpulan. Tahap-tahap yang dilakukan pada penelitian ini yaitu:

1. Tahap Perencanaan

Kegiatan yang peneliti lakukan pada tahap ini meliputi: menentukan lokasi penelitian, menyusun instrumen penelitian, melakukan validasi instrumen penelitian, mengurus surat izin penelitian, dan menentukan waktu penelitian yang dikonsultasikan dengan guru matematika kelas VII C SMP PGRI 6 Malang.

2. Tahap Pelaksanaan

Pelaksanaan dilakukan dengan menyampaikan materi segiempat dan tahapan Polya. Kemudian memberikan soal tes kemampuan pemecahan masalah dan dianalisis, melakukan wawancara dan dianalisis, membuat dokumentasi pelaksanaan penelitian, dan mendeskripsikan hasil tes berdasarkan tahapan pemecahan masalah Polya dan hasil wawancara serta membuat kesimpulan sebagai jawaban dari masalah dalam penelitian.

\section{HASIL DAN PEMBAHASAN}

Hasil tes kemampuan pemecahan masalah siswa diperiksa dan dikoreksi, kemudian dikelompokkan sesuai dengan tingkat kemampuan pemecahan masalah yang dimiliki dan dilakukan wawancara sampai ditemukan kesamaan jawaban untuk dijadikan subjek penelitian. Berikut jumlah siswa pada masing-masing tingkat kemampuan pemecahan masalah.

Tabel 1. Jumlah Siswa Pada Masing-Masing Tingkatan Kemampuan Pemecahan Masalah

\begin{tabular}{|c|c|c|}
\hline Tingkat Kemampuan & Jumlah Siswa & Inisial Nama Siswa \\
\hline Tingkat 1 & 4 & MRF, CNWA, CA, ODRD \\
\hline Tingkat 2 & 5 & DRD, ATR, ZCP, ADS, MPS \\
\hline Tingkat 3 & 8 & RDAP, IF, RPDR, MATPY, DPS, NHI, MI, YTP \\
\hline Tingkat 4 & 6 & LM, NZR, KHI, GRA, HF, FIY \\
\hline
\end{tabular}


1. Hasil tes LM dari tingkat 4

Berikut hasil pengerjaan LM dapat dilihat pada Gambar 1 berikut.

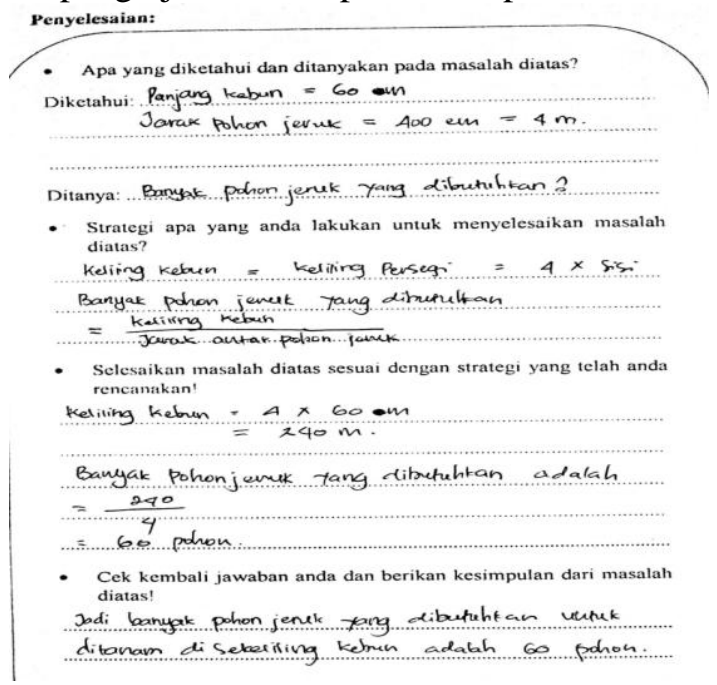

Gambar 1. Hasil tes LM soal nomor 1

Berdasarkan hasil kerja LM, peneliti menganalisis kemampuan pemecahan masalah LM. Pada tahap memahami masalah LM mampu menuliskan informasi yang diberikan pada soal dengan baik, mampu merumuskan rencana penyelesaian dan mampu melaksanakan rencana penyelesaian dengan baik. Namun pada tahap memeriksa kembali LM belum mampu memeriksa kembali hasil pekerjaannya, LM hanya mampu menuliskan kesimpulan dari hasil perhitungannya saja.

2. Hasil tes RDAP dari tingkat 3

Berikut hasil pengerjaan RDAP dapat dilihat pada Gambar 2 berikut.

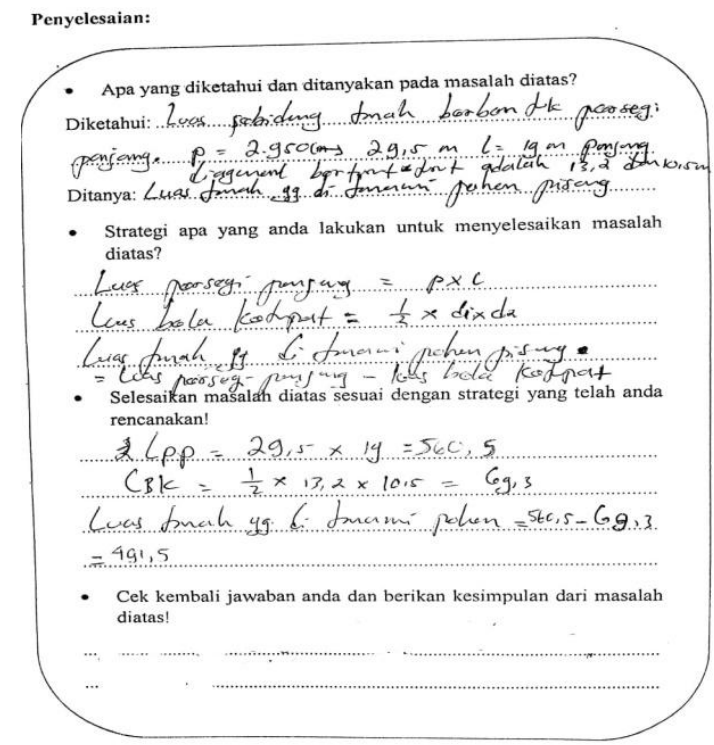

Gambar 2. Hasil tes RDAP soal nomor 2

Berdasarkan hasil kerja RDAP, peneliti menganalisis kemampuan pemecahan masalah RDAP. pada tahap memahami masalah RDAP mampu menuliskan informasi yang diberikan dengan tepat yaitu menentukan apa yang diketahui dan ditanyakan dengan benar. Pada tahap menyusun rencana penyelesaian dan melaksanakan rencana penyelesaian RDAP mampu menyelesaikan dengan baik dan hasil perhitungan yang RDAP tuliskan tepat. Namun pada tahap memeriksa kembali RDAP tidak menuliskan jawaban. 
3. Hasil tes DRD dari tingkat 2

Berikut hasil pengerjaan DRD dapat dilihat pada Gambar 3 berikut.

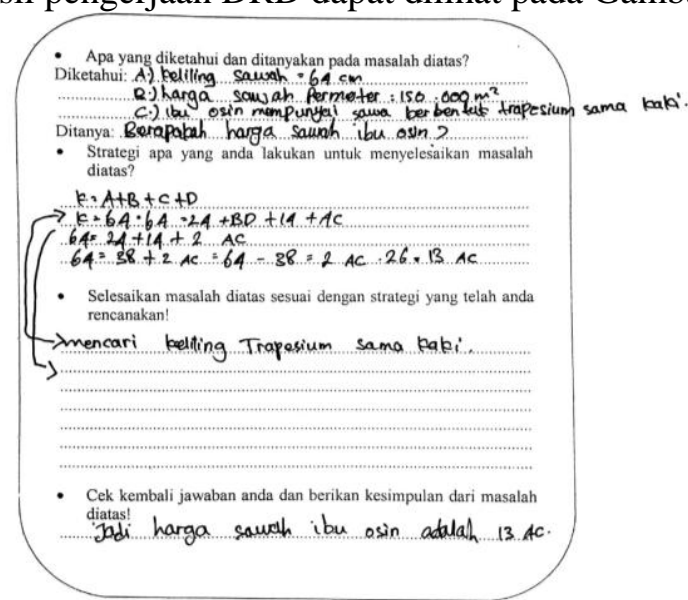

Gambar 3. Hasil tes DRD soal nomor 3

Berdasarkan hasil pekerjaan DRD, peneliti menganalisis kemampuan pemecahan masalah DRD. Pada tahap memahami masalah DRD mampu menentukan apa yang diketahui dan ditanyakan dengan tepat. Namun pada tahap membuat rencana penyelesaian DRD kurang mampu sehingga pada tahap melaksanakan rencana penyelesaian DRD tidak menuliskan jawaban dan pada tahap memeriksa kembali DRD hanya menuliskan kesimpulan seperti yang terlihat pada gambar 3. Namun kesimpulan yang DRD tuliskan masih belum tepat.

4. Hasil tes MRF dari tingkat 1

Berikut hasil pengerjaan MRF dapat dilihat pada Gambar 4 berikut.

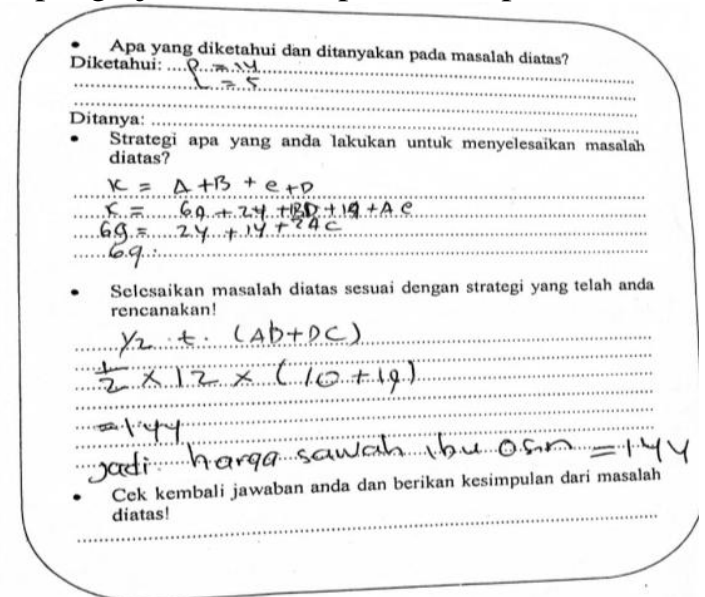

Gambar 4. Hasil tes MRF soal nomor 3

Berdasarkan hasil pekerjaan MRF, peneliti menganalisis kemampuan pemecahan masalah MRF. Pada tahap memahami masalah MRF belum mampu menuliskan informasi yang diberikan pada soal. Selain itu, MRF juga belum mampu membuat rencana penyelesaian masalah. Pada tahap melasanakan rencana penyelesaian MRF masih kurang tepat melakukan perhitungan dan juga hanya menuliskan kesimpulan dan tidak memeriksa kembali jawabannya.

\section{PEMBAHASAN}

Siswa yang tergolong pada tingkat 1 dalam menyelesaikan soal cerita segiempat terdapat 4 orang. Kemampuan pemecahan masalah siswa rendah disebabkan oleh kurangnya pemahaman siswa terhadap materi segiempat dan materi pendukung lainnya. Lestanti (2016) mengemukakan dalam menyelesaikan masalah matematika diharapkan siswa memahami masalah yang diberikan serta kreatif memilih dan menelaah persyaratan dan konsep yang tepat untuk membuat langkah penyelesaian serta menggunakan keterampilan yang telah dimiliki sebelumnya. Kemampuan subjek yang berada pada tingkat ini masih rendah dalam menyelesaikan soal tes nomor 1, 2, dan 3. Pada tahap memahami masalah subjek hanya mampu 
menuliskan apa yang ditanyakan. Kemudian pada tahap menyusun rencana subjek tidak menuliskan strategi atau rencana penyelesaian. Selanjutnya pada tahap melaksanakan rencana penyelesaian subjek belum mampu melakukan perhitungan dengan tepat dan juga rumus yang digunakan masih kurang tepat untuk menyelesaikan masalah dan subjek belum mampu memeriksa kembali jawaban. selain itu terdapat beberapa subjek yang tidak menjawab soal nomor 2 dan 3.

Siswa yang tergolong pada tingkat 2 dalam menyelesaikan soal cerita segiempat terdapat 5 orang. Kemampuan pemecahan masalah subjek tingkat 2 mengalami kesulitan untuk mengkaitkan yang diketahui dan ditanyakan, sehingga rencana pemecahan masalah yang dibuat pun sama tidak relevan dengan materi segiempat. Karlimah (2010) menyatakan bahwa dalam membuat rencana penyelesaian carilah hubungan antara informasi atau petunjuk yang diberikan untuk menghitung variabel yang tidak diketahui. Kemampuan subjek tingkat 2 saat mengerjakan soal nomor 1, 2, dan 3 pada tahap memahami masalah sangat baik. Pada tahap menyusun rencana penyelesaian terdapat subjek yang mampu membuat rencana penyelesaian pada soal nomor 1 dan melaksanakan rencana penyelesaian dengan baik. Namun pada soal nomor 2 dan 3, 5 subjek tersebut belum mampu menyusun rencana penyelesaian, melaksanakan rencana penyelesaian dan memeriksa kembali jawabannya.

Siswa yang tergolong pada tingkat 3 dalam menyelesaikan soal cerita segiempat terdapat 8 orang. Namun subjek tidak memeriksa jawaban disebabkan karena subjek tidak terbiasa melakukan pekerjaan memeriksa jawaban kembali. Hal ini selaras dengan hasil penelitian Sri Adi Widodo (2013: 116) pada tahap memeriksa kembali siswa yang tidak melakukan kegiatan apapun dikarenakan siswa tidak mengetahui apa yang harus dilakukan pada tahapan ini dan siswa tidak terbiasa melakukan tahapan memeriksa kembali dalam menyelesaikan masalah matematika. Kemampuan subjek tingkat 3 saat menyelesaikan soal nomor 1, 2, dan 3 pada tahap memahami masalah, menyusun rencana penyelesaian, dan melaksanakan rencana penyelesaian sudah baik namun pada tahap memeriksa kembali terdapat beberapa subjek yang tidak menuliskan jawaban dan hanya menuliskan kesimpulan.

Siswa yang tergolong pada tingkat 4 dalam menyelesaikan soal cerita segiempat terdapat 6 orang. Namun pada tahap memeriksa kembali subjek hanya mampu menuliskan kesimpulan dari hasil pekerjaannya tanpa memeriksa kembali jawabannya. Hal ini selaras dengan hasil penelitian Sukoriyanto (2016) yang menyatakan bahwa siswa telah memahami masalah, telah mampu menyusun rencana dan telah mampu menerapkan pemecahan masalah, namun para siswa tidak mengecek kembali masalah yang diberikan. Kemampuan subjek tingkat 4 saat menyelesaikan soal nomor 1, 2, dan 3 pada tahap memahami masalah, menyusun rencana penyelesaian, dan melaksanakan rencana penyelesaian sudah sangat baik. Namun pada tahap memeriksa kembali semua subjek yang berada pada tingkat ini hanya mampu menuliskan kesimpulan dan belum mampu memeriksa kembali jawaban.

\section{PENUTUP}

Berdasarkan analisis kemampuan pemecahan masalah matematika siswa berdasarkan tahapan Polya dalam menyelesaikan soal tes materi segiempat kelas VII C SMP PGRI 6 Malang, maka kesimpulan dari penelitian ini adalah sebagai berikut:

1. Kemampuan 4 orang subjek yang digolongkan pada tingkat 1 dalam memecahkan masalah matematika berdasarkan tahapan Polya dikarenakan subjek tidak mampu menuliskan secara lengkap apa yang diketahui dan apa yang ditanyakan soal serta belum mampu menentukan rumus yang akan digunakan untuk menyelesaikan masalah dan melakukan perhitungan dengan benar serta memeriksa kembali jawaban.

2. Kemampuan 5 orang subjek yang digolongkan pada tingkat 2 dalam memecahkan masalah matematika berdasarkan tahapan Polya dikarenakan subjek tidak mampu menuliskan rumus bangun datar, membuat konsep yang berkaitan dengan soal yang diberikan, dan menyusun langkah-langkah penyelesaian agar soal dapat diselesaikan secara sistematis.

3. Kemampuan 8 orang subjek yang digolongkan pada tingkat 3 dalam memecahkan masalah berdasarkan tahapan Polya dikarenakan subjek malas dan tidak terbiasa memeriksa ulang dan meneliti setiap langkah yang dilakukan dari hasil jawaban yang diperoleh. 
4. Kemampuan 6 orang subjek yang digolongkan pada tingkat 4 dalam memecahkan masalah berdasarkan tahapan Polya dikarenakan subjek mampu melaksanakan 4 tahapan Polya. Namun pada tahap memeriksa kembali subjek hanya mampu menuliskan kesimpulan dari hasil pekerjaannya. Subjek tidak terbiasa memeriksa ulang dan meneliti setiap langkah yang dilakukan dari hasil jawaban yang diperoleh.

Berdasarkan hasil penelitian yang dilakukan di SMP PGRI 6 Malang diperoleh bahwa mayoritas siswa kelas VII C berada pada tingkat 3 yaitu sebesar . Saran bagi guru adalah sebaiknya guru mengetahui kemampuan pemecahan masalah siswa supaya pembelajarannya lebih efektif dan berhasil. Sedangkan saran bagi peneliti lain adalah diharapkan supaya melakukan penelitian pada bidang-bidang lain seperti geometri, statistika dan lain-lain.

\section{DAFTAR PUSTAKA}

Bocro, P. \& Dapunto, C. (2007). Problem solving in mathematics education in Italy:dreams and reality. ZDM Mathematics Education (2007)

Chilmiyah, Siti Machmurotun. (2014). Kemampuan Berpikir Siswa Dalam Menyelesaikan Soal Cerita Matematika (The Thinking Ability Of Students In Solving Mathematics Story Problems). Jurnal Pendidikan Matematika STKIP PGRI Sidoarjo. Vol.2 (2): 238

Dewi, S. K., Suardjana., \& Sumantri. (2014). Penerapan Model Polya untuk Meningkatkan Hasil Belajar dalam Memecahkan Soal Cerita Matematika Siswa Kelas V. Jurnal Mimbar PGSD Universitas Ganesha Jurusan PGSD.

Dewimarni, S. 2017. Kemampuan Komunikasi dan Pemahaman Konsep Aljabar Linear Mahasiswa Universitas Indonesia 'YPTK' Padang. Jurnal Pendidikan Matematika, Vol 8 (1): 53-62.

Herlambang. (2013). Analisis Kemampuan Pemecahan Masalah Matematika Siswa Kelas VII-A SMP Negeri 1 Kepahiang tentang Bangun Datar Ditinjau dari Teori Van Hiele. [online]. Tersedia: http://repository.unib.ac.id/8426/2/I,II,III,2-13-her.FI.pdf [27 Februari 2019].

Karlimah. (2010). "Kemampuan Komunikasi dan Pemecahan Masalah Matematis Mahasiswa Pendidikan Guru Sekolah Dasar Melalui Pembelajaran Berbasis Masalah". Jurnal Pendidikan Vol 11 (2): 51-60.

Lestanti, M.M., Isnarto, \& Supriyono. 2016. Analisis Kemampuan Pemecahan Masalah Ditinjau dari Karakteristik Cara Berpikir Siswa dalam Model Problem Based Learning. Unnes Journal of Mathematics Education, Vol 5 (1): 16-23.

Moleong, L. J. (2013). Metodologi Penelitian Kualitatif. Edisi revisi. Bandung: PT Remaja Rosdakarya.

Ngilawajan, Darma Andreas. (2013). Proses Berpikir Siswa SMAdalam Memecahkan Masalah MatematikaMateri Turunan Ditinjau dari Gaya Kognitif Field Independent dan Field Dependent. Jurnal PEDAGOGIA. Vol 2 (1)

Somawati. 2018. Peran Efikasi Diri (Self Efficacy) Terhadap Kemampuan Pemecahan Masalah Matematika. Jurnal Konseling dan Pendidikan, Vol 6 (1): 39-45.

Sugiman, Kusumah, Y.S., Sabandar,J. (2009). Mathematics Problem Solving in Realistic Mathematics. Jurnal Pendidikan Matematika. PARADIKMA.

Sukoriyanto, dkk. (2016). Students' Errors in Solving the Permutation and Combination Problems Based on Problem Solving Steps of Polya. International Education Studies. Canadian Center of Science and Education. Vol. 9 (2).

Suratmi, S., \& Purnami, A. S. (2017). Pengaruh Strategi Metakognitif Terhadap Kemampuan Pemecahan Masalah Matematika Ditinjau dari Persepsi siswa 
Terhadap Pelajaran Matematika. UNION.: Jurnal Ilmiah Pendidikan Matematika, Vol 5 (2).

Sri Adi W. (2013). Analisis Kesalahan Dalam Pemecahan Masalah Divergensi Tipe Membuktikan Pada Mahasiswa Matematika. Jurnal Pendidikan dan pengajaran (JPP). Vol 46 (2): 106 - 113. Denpasar: Universitas Pendidikan Ganesha.

White, Allan L. (2010). Numeracy, Literacy, and Newman's Error Analysis. Journal of Science and Mathematics Education in Southeast Asia. 